\title{
Analisis Paparan Timbal (PB) Pada Petugas Stasiun Pengisian Bensin Umum (SPBU) CV. Arba di Kota Palu
}

\author{
Analysis of lead (pb) Exposure in Gas Station Worker (SPBU) CV. Arba in Palu City
}

\author{
Zhanaz Tasya \\ Departemen Epidemiologi, Fakultas Kesehatan Masyarakat, Universitas Muhammadiyah Palu \\ zhanaz_tasya@gmail.com
}

\begin{abstract}
Abstrak
Polusi logam berat termasuk timbal $(\mathrm{Pb})$ merupakan masalah yang serius di negara maju maupun negara berkembang seperti indonesia. Polusi timbal berkaitan erat dengan proses pertambangan, asap kendaraan bermotor serta Industri yang menggunakan bahan baku timbal $(\mathrm{Pb})$ seperti bahan bakar minyak yang mengandung bahan kimia beracun. Bahan bakar minyak dapat menghasilkan uap atau gas diudara yang menyebabkan dampak buruk bagi kesehatan manusia.Penelitian ini bertujuan untuk mengetahui paparan timbal $(\mathrm{Pb})$ pada petugas SPBU CV.Arba. Penelitian ini menggunakan desain penelitian obeservasional analitik dengan pendekatan Cross sectional study. Sampel dalam penelitian ini diambil dengan menggunakan metode pengambilan sampel Total Sampling yaitu sebesar 40 responden.Hasil penelitian ini adalah ada hubungan yang bermakna antara paparan timbal $(\mathrm{Pb})$ dengan jam kerja responden dengan nilai $p=0,004$, ada hubungan yang bermakna antara paparan timbal $(\mathrm{Pb})$ dengan masa kerja responden dengan nilai $p=0,000$, dan hubungan yang bermakna antara paparan timbal $(\mathrm{Pb})$ dengan kebiasaan merokok dengan nilai $p=0,001$.Kesimpulan dari penelitian ini adalah $\mathrm{Pb}$ dapat terakumulasi didalam tubuh dalam kurun waktu yang lama,akumulasi timbal $(\mathrm{Pb})$ didalam tubuh khususnya kepada para petugas SPBU dapat dipengaruhi oleh beberapa faktor diantaranya ialah masa kerja yang lama, jam kerja yang lebih dari jam kerja normal, dan kebiasaan merokok. Selain melaui spesimen darah dan urin, akumulasi timbal $(\mathrm{Pb})$ didalam tubuh seseorang juga dapat dideteksi melalui spesimen yang lain seperti rambut karna rambut dapat menyimpan akumulasi zat kimia didalam tubuh dalam kurun waktu yang lama.
\end{abstract}

Kata Kunci : Analisis Timbal (PB); Petugas SPBU

\begin{abstract}
Heavy metal pollution including lead (Pb) is a serious problem in both developed and developing countries such as Indonesia. Lead pollution is closely related to the mining process, motor vehicle fumes and industries that use lead (Pb) as fuel oil which contains toxic chemicals. Fuel oil can produce steam or gas in the air which causes adverse effects on human health. This study aims to determine the exposure of lead $(\mathrm{Pb})$ to $\mathrm{CV}$. Arba gas station officers. This study uses an analytic observational study design with a cross sectional study approach. The sample in this study was taken using the Total Sampling method that is equal to 40 respondents. The results of this study is that there is a significant relationship between exposure to lead (Pb) with the working hours of respondents with a value of $p=0.004$, there is a significant relationship between exposure to lead (PB) with the employment period of respondents with $p=0,000$, and a significant relationship between exposure to lead (Pb) and smoking habits with $p$ value $=0.001$. The conclusion of this study is that Pb can accumulate in the body for a long time, lead accumulation $(\mathrm{Pb})$ in the body, especially to gas station officers, it can be influenced by several factors, including long working hours, working hours that are more than normal working hours, and smoking habits. In addition to blood and urine specimens, the accumulation of lead $(\mathrm{Pb})$ in a person's body can also be detected through other specimens such as hair because hair can store accumulation of chemicals in the body for a long time.
\end{abstract}

Keywords: Analysis Lead (PB); workers 


\section{PENDAHULUAN}

Polusi logam berat termasuk timbal $(\mathrm{Pb})$ merupakan masalah yang serius di negara maju maupun negara berkembang seperti indonesia. Polusi timbal berkaitan erat dengan proses pertambangan, asap kendaraan bermotor serta Industri yang menggunakan bahan baku timbal $(\mathrm{Pb})$ seperti bahan bakar minyak yang mengandung bahan kimia beracun. Bahan bakar minyak dapat menghasilkan uap atau gas diudara yang menyebabkan dampak buruk bagi kesehatan manusia (1). Sebagaimana penelitian menunjukkan perubahan histologis paru setelah dipaparkan timbal $(\mathrm{Pb})$ selama 4,8, dan 12 jam (2). Setelah itu terlihat kelainan pada histologis paru mencit yaitu berupa oedem pada kelompok perlakuan. Jumlah alveoli oedem pada kelompok perlakuan lebih banyak daripada kelompok kontrol. Hal ini menunjukkan bahwa paparan timbal dapat menyebabkan terjadinya akumulasi cairan yang berlebihan di dalam sel, ruang antar sel, dan pada rongga alveoli paru-paru. Hal ini mengakibatkan terganggunya pertukaran gas oksigen dan kerbondiksida di paru-paru sehingga membuat seseorang kesulitan dalam bernafas.

Keracunan timbal $(\mathrm{Pb})$ sering terjadi pada kelompok masyarakat yang berisiko tinggi seperti pekerja bengkel, pekerja jalan tol, supir angkutan umum, serta petugas pengisi bahan bakar di SPBU. Petugas SPBU adalah salah satu kelompok masyarakat yang rentan terpapar timbal $(\mathrm{Pb})$. Hal ini didukung oleh jam kerja yang lebih dari 8 jam/perhari dengan jangka waktu yang lama dan tanpa menggunakan alat pelindung diri berupa masker untuk mengurangi atau menghilangkan efek paparan uap atau gas yang dihasilkan oleh bahan bakar minyak. Akumulasi timbal $(\mathrm{Pb})$ didalam tubuh dapat dideteksi melalui darah, tulang, dan rambut. Pada rambut, $\mathrm{Pb}$ terikat pada gugus sulfihidril sehingga kandungan timbal $(\mathrm{Pb})$ pada rambut dapat dijadikan indikator pencemaran timbal. Olehnya menggunakan rambut sebagai indikator dapat menjadi sebuah metode yang mudah untuk menganalisis tingkat pencemaran timbal $(\mathrm{Pb})$ yang terakumulasi didalam tubuh (3).

\section{METODE}

Penelitian ini menggunakan desain penelitian obeservasional analitik dengan pendekatan Cross sectional study. Penelitian ini dilaksananakan pada tiga SPBU (Stasiun Pengisian Bensin Umum) yang berada dibawah naungan CV. ARBA di Kota Palu, diantaranya adalah SPBU karya putra arba, SPBU M Hasan, dan SPBU PT Ricita Putra Arba Bersatu. Populasi pada penelitian ini adalah seluruh operator yang bekerja di SPBU karya putra arba, SPBU M Hasan, dan SPBU PT Ricita Putra Arba Bersatu yaitu sebanyak 40 orang. Sampel dalam penelitian ini diambil dengan menggunakan metode pengambilan sampel Total Sampling yaitu sebesar 40 responden. Pengumpulan data dilakukan melaui dua cara yaitu data sekunder dan data primer. Data sekunder diperoleh dari instansi terkait yaitu berupa data profil dari ketiga SPBU tersebut sedangkan data primer diperoleh melaui metode wawancara langsung menggunakan kuesioner serta melakukan pengambilan sampel rambut pada operator yang diwawancarai. Sampel tersebut diuji laboratorium dengan menggunakan metode Spektrofotometri Serapan Atom untuk mengetahui kadar Timbal $(\mathrm{Pb})$ yang terkandung pada tubuh operator tersebut. Jika hasil uji mendapatkan kadar timbal $(\mathrm{Pb})$ rambut sebesar $\leq 20 \mu \mathrm{g} / \mathrm{g}$ hal ini mengindikasikan kadar timbal $(\mathrm{Pb})$ pada tubuh petugas berada pada kondisi normal, sebaliknya Jika diperoleh kadar timbal $(\mathrm{Pb})$ rambut $>20 \mu \mathrm{g} / \mathrm{g}$ hal ini mengindikasikan kadar timbal $(\mathrm{Pb})$ pada tubuh petugas berada pada kondisi tidak normal. Analisis data pada penelitian ini dilakukan melalui dua tahap yaitu analisis Univariat dan analisis Bivariat.

\section{HASIL}

Analisis univariat pada tabel 1 menunjukkan bahwa karateristik responden berdasarkan umur terbanyak pada kelompok umur 26-35 tahun yaitu sebesar 20 responden (44,5\%). Berdasarkan tingkat pendidikan terbanyak yaitu SMA sebesar 31 responden (68,9\%). Sebagian besar responden memiliki masa kerja lebih dari 2th yaitu sebanyak 33 
responden $(73,3 \%)$, dan sebagian besar responden memiliki jam kerja normal atau $\leq 8 \mathrm{jam} / \mathrm{hari}$ yaitu sebanyak 36 responden (80.0\%). Responden yang tidak tahu manfaat dan aturan pemakaian APD lebih banyak dibandingkan dengan responden yang tahu yaitu sebesar 35 responden (77,8\%). Berdasarkan hasil analisis laboratorium diperoleh hasil paparan timbal $(\mathrm{Pd})$ pada responden terbanyak memiliki kadar timbal yang tidak normal pada tubuhnya atau lebih dari $20 \mu \mathrm{g} / \mathrm{g}$ yaitu sebesar 37 responden (82,2\%). Analisis bivariat pada tabel 2 menunjukkan bahwa dari 45 responden yang terlibat dalam penelitian ini, yang memiliki Jam kerja tidak normal dengan paparan timbal $(\mathrm{Pb})$ tidak normal sebanyak 4 responden $(44,4 \%)$, dan responden yang memiliki jam kerja tidak normal dengan paparan timbal $(\mathrm{Pb})$ normal sebanyak 5 responden $(55,6 \%)$. Sedangkan responden yang memiliki Jam kerja normal dengan paparan timbal $(\mathrm{Pb})$ tidak normal sebanyak 33 responden $(91,7 \%)$, dan responden yang memiliki jam kerja normal dengan paparan timbal $(\mathrm{Pb})$ normal sebanyak 3 responden $(8,3 \%)$. Hasil analisis statistik dengan mengunakan uji chi-square menunjukkan hubungan yang bermakna antara paparan timbal $(\mathrm{Pb})$ dengan jam kerja responden dengan nilai $p=0,004(p<0,05)$.

Tabel 3 menunjukkan bahwa dari 45 responden yang terlibat dalam penelitian ini, yang memiliki masa kerja Lama ( $>2$ th) dengan paparan timbal $(\mathrm{Pb})$ tidak normal sebanyak 32 responden $(97 \%)$, dan responden yang memiliki masa kerja lama dengan paparan timbal $(\mathrm{Pb})$ normal sebanyak 1 responden $(3,0 \%)$. Sedangkan responden yang memiliki masa kerja baru ( $\leq$ th) dengan paparan timbal $(\mathrm{Pb})$ tidak normal sebanyak 5 responden $(41,7 \%)$, dan responden yang memiliki masa kerja baru dengan paparan timbal $(\mathrm{Pb})$ normal sebanyak 7 responden (58,3\%). Hasil analisis statistik dengan mengunakan uji chi-square menunjukkan hubungan yang bermakna antara paparan timbal $(\mathrm{Pb})$ dengan masa kerja responden dengan nilai $p=0,000(p<0,05)$. Tabel 4 menunjukkan bahwa dari 45 responden yang terlibat dalam penelitian ini, yang merokok dengan paparan timbal $(\mathrm{Pb})$ tidak normal sebanyak 34 responden $(94,4 \%)$, dan responden yang merokok dengan paparan timbal $(\mathrm{Pb})$ normal sebanyak 2 responden $(5,6 \%)$. Sedangkan responden yang tidak merokok dengan paparan timbal $(\mathrm{Pb})$ tidak normal sebanyak 3 responden $(33,3 \%)$, dan responden yang tidak merokok dengan paparan timbal $(\mathrm{Pb})$ normal sebanyak 6 responden (66,7\%). Hasil analisis statistik dengan mengunakan uji chi-square menunjukkan hubungan yang bermakna antara paparan timbal $(\mathrm{Pb})$ dengan kebiasaan merokok dengan nilai $p=0,001(p<0,05)$.

\section{PEMBAHASAN}

Hasil analisis $\mathrm{Pb}$ yang diuji melalui sampel rambut responden menunjukkan bahwa rata-rata kadar timbal $(\mathrm{Pb})$ pada tubuh responden berkisar 22-23 $\mu \mathrm{g} / \mathrm{g}$, hal ini membuktikan bahwa rata-rata responden memiliki kadar timbal $(\mathrm{Pb})$ yang tidak normal dalam tubuhnya yaitu lebih dari $20 \mu \mathrm{g} / \mathrm{g}$. Hasil analisis bivariat pada tabel 2 telah membuktikan bahwa terdapat hubungan yang bermakna antara paparan timbal $(\mathrm{Pb})$ dengan masa kerja dengan nilai $p=0,001(p<0,05)$, hal ini sejalan dengan hasil penelitian subagiada yang menemukan adanya hubungan antara lama bekerja dengan kandungan timbal $(\mathrm{Pb})$ dalam tubuh seseorang, menurut subagiada interaksi yang lama antara petugas SPBU dengan bahan bakar dapat menyebabkan petugas SPBU rentan terhadap paparan timbal $(\mathrm{Pb})$, hal ini dapat terjadi akibat adanya penguapan bahan bakar ke udara, bahan bakar tersebut dihirup secara langsung melalui saluran pernafasan kemudian mengendap dan terakumulasi didalam tubuh (4). Iklim merupakan salah satu faktor yang dapat mempengaruhi perubahan kualitas udara, iklim berperan meningkatkan jumlah spora jamur, partikel, debu, serta beberapa polutan yang dapat menyerang saluran pernafasan pada individu yang rentan (5).

Demikian halnya dengan penelitian yang dilakukan oleh Nurjazuli dkk pada opertor SPBU di Samarinda yang membuktikan bahwa lama kerja merupakan faktor yang dominan terhadap tingginya kadar $\mathrm{Pb}$ dalam tubuh. Hal ini disebabkan oleh sifat akumulatif timbal $(\mathrm{Pb})$. Olehnya apabila seseorang berada pada lingkungan yang tercemar 
timbal $(\mathrm{Pb})$ maka tubuhnya akan mengandung timbal $(\mathrm{Pb})$ yang terhirup dari aktivitas penafasan. Sehingga semakin lama seseorang berada pada lingkungan itu maka semakin tinggi risiko dari paparan timbal $(\mathrm{Pb})$ yang akan diterima oleh orang tersebut (6). Konsentrasi timbal $(\mathrm{Pb})$ dalam rambut manusia juga behubungan dengan lingkungan dari manusia itu sendiri, diantaranya adalah makanan, minuman, kondisi geografis ligkungan, industri kimia, maupun kontaminasi dari tumbuhan yang tumbuh pada tanah yang mengandung logam (7).

Hasil analisis bivariat pada tabel 3 membuktikan adanya hubungan yang bermakna antara paparan timbal $(\mathrm{Pb})$ dengan jam kerja dengan nilai $p=0,004(p<0,05)$, hal ini sejalan dengan hasil penelitian Girsang yang menemukan adanya hubungan antara jam kerja dengan kandungan timbal $(\mathrm{Pb})$ dalam tubuh $(8)$. Seorang pekerja bisa menyerap timbal $(\mathrm{Pb})$ sebesar $400 \mu \mathrm{g}$ selama 8 jam, ditambah dengan 20-30 $\mu \mathrm{g} / \mathrm{hari}$ yang diperoleh dari minuman, makanan, rokok, dan udara. Demikian halnya pada peneitian yang dilakukan oleh Sinta dkk yang membuktikan adanya hubungan antara jam kerja dengan paparan timbal $(\mathrm{Pb})$ dalam tubuh, dari 15 responden yang diteliti, sebanyak 9 responden $(60 \%)$ yang bekerja lebih dari 8 jam/hari memiliki kadar timbal $(\mathrm{Pb})$ yang tidak normal dalam tubuhnya. Dengan lamanya seseorang bekerja $>8$ jam/hari secara terus menerus akan mengurangi jam istirahat dan memperpanjang waktu terjadinya paparan. Hal ini mengakibatkan tubuh dan sistem imunitas semakin menurun dan semakin rentan terserang penyakit (9).

Hasil analisis bivariat pada tabel 4 membuktikan adanya hubungan yang bermakna antara paparan timbal $(\mathrm{Pb})$ kebiasaan merokok dengan nilai $p=0,001(p<0,05)$. Hal ini sejalan dengan penelitian yang membuktikan adanya hubungan antara paparan timbal $(\mathrm{Pb})$ dengan kebiasaan merokok, dari 20 responden yang diteliti, sebanyak 13 responden $(68,4 \%)$ kelompok perokok memiliki kadar $\mathrm{Hb}$ yang tidak normal atau rendah, yang tidak lain ketidaknormalan tersebut disebabkan oleh senyawa toksik yang terkandung pada rokok dan mempengaruhi kerja dari sistem paru-paru, penurunan sistem kerja organ mempermudah timbal $(\mathrm{Pb})$ masuk kedalam saluran pernafasan, kemudian jaringan paru-paru dan pembuluh darah. Darah yang terkontaminasi timbal $(\mathrm{Pb})$ akan memperpendek sel darah merah dan menurunkan kadar eritrosit sehingga seseorang dapat mengalami anemia (10). Einbenstener L dalam penelitiannya juga membuktikan bahwa kebiasaan merokok mempunyai hubungan yang kuat dengan peningkatan kadar timbal $(\mathrm{Pb})$ dalam tubuh karena kebiasaan merokok dapat menyebabkan adanya kelainan silia dan iritasi pada saluran pernafasan sehingga penyerapan timbal $(\mathrm{Pb})$ melalui saluran pernafasan akan lebih mudah (11).

\section{KESIMPULAN}

Penelitian ini menyimpulkan bahwa timbal $(\mathrm{Pb})$ dapat terakumulasi didalam tubuh dalam kurun waktu yang lama,akumulasi timbal $(\mathrm{Pb})$ didalam tubuh khususnya kepada para petugas SPBU dapat dipengaruhi oleh beberapa faktor diantaranya ialah masa kerja yang lama, jam kerja yang lebih dari jam kerja normal, dan kebiasaan merokok. Selain melaui spesimen darah dan urin, akumulasi timbal $(\mathrm{Pb})$ didalam tubuh seseorang juga dapat dideteksi melalui spesimen yang lain seperti rambut karna rambut dapat menyimpan akumulasi zat kimia didalam tubuh dalam kurun waktu yang lama. Sekiranya hasil penelitian ini dapat menjadi bahan rekomendasi bagi pihak SPBU untuk lebih disiplin dalam menerapkan aturan-aturan kesehatan dan keselamatan kerja di lingkungan kerjanya khususnya terkait dengan penggunaan alat pelindung diri seperti masker, hal ini sangat penting bagi kesehatan dan keselamatan para pekerja. 


\section{DAFTAR PUSTAKA}

1. NOVDIAN S. GAMBARAN KADAR TIMBAL $(\mathrm{Pb})$ DALAM RAMBUT SOPIR BUS YANG MELEWATI JALUR TRANSPORTASI UJUNG GADING-PADANG PADA TAHUN 2016: universitas andalas; 2016.

2. Putri VP. HUBUNGAN ANTARA MASA KERJA DENGAN KEJADIAN GINGIVAL LEAD LINE PADA PEDAGANG KAKI LIMADI KOTA SEMARANG: Faculty of Medicine; 2010.

3. Marianti A, Prasetya AT. Rambut sebagai Bioindikator Pencemaran Timbal pada Penduduk di Kecamatan Semarang Utara. Biosaintifika: Journal of Biology \& Biology Education. 2013;5(1).

4. Subagiada K. Penentuan Kadar Timbal $(\mathrm{Pb})$ Dengan Bioindikator Rambut Pada Pekerja SPBU Di Kota Samarinda. Skripsi Jurusan Fisika FMIPA, Universitas Mulawarman. 2011.

5. Gusnita $\mathrm{D}$. Pencemaran logam berat timbal $(\mathrm{Pb})$ di udara dan upaya penghapusan bensin bertimbal. Berita Dirgantara. 2012;13(3).

6. Nurjazuli B. Hubungan Lama Kerja Dengan Kadar Timah Hitam (Pb) Dalam Darah Operator SPBU Di Samarinda Kalimantan Timur. Media kesehatan masyarakat Indonesia. 2003;2(1):18-21.

7. Perumal AS, Thangamani A. ATOMIC ABSORPTION SPECTROPHOTOMETRIC DETERMINATION OF HEAVY METALS LEAD AND CHROMIUM LEVELS IN HUMAN HAIR OF PEOPLE LIVING IN KATPADI AND YELAGIRI HILLS OF VELLORE DISTRICT. International Journal of Research in Ayurveda \& Pharmacy. 2011;2(5).

8. Girsang E. Hubungan kadar timbal di udara ambien dengan timbal dalam darah pada pegawai Dinas Perhubungan Terminal Antar Kota Medan 2008.

9. Hariani S, Wahyuni M. Analisis Kandungan Timbal $(\mathrm{Pb})$ pada Operator SPBU 61.751. 02 di Jalan Slamet Riyadi Samarinda. 2014.

10. Hasan W, Matondang AR, Syahrin A, Wahyuni CU. Pengaruh Jenis Kelamin dan Kebiasaan Merokok terhadap Kadar Timbal Darah. Kesmas: National Public Health Journal. 2013:164-8.

11. Eibensteiner L, Sanz ADC, Frumkin H, Gonzales C, Gonzales GF. Lead exposure and semen quality among traffic police in Arequipa, Peru. International journal of occupational and environmental health. 2005;11 (2):161-6.

12. Zhao G, Perilla JR, Yufenyuy EL, Meng X, Chen B, Ning J, et al. Mature HIV-1 capsid structure by cryoelectron microscopy and all-atom molecular dynamics. Nature. 2013;497(7451):643.

13. Cimermancic P, Gulbahce N, Johnson JR, Mcgovern KE, Clarke SC, Shales M, et al. Global landscape of HIV - human protein complexes. Nature. 2012;481(7381):5-10. 
Tabel 1

Distribusi Frekuensi Berdasarkan Karateristik Responden

\begin{tabular}{|c|c|c|}
\hline Variabel & $\mathbf{N}$ & $\begin{array}{c}\text { Presentase } \\
(\%)\end{array}$ \\
\hline \multicolumn{3}{|l|}{ Umur } \\
\hline $15-25$ th & 10 & 22,2 \\
\hline $26-35$ th & 20 & 44,5 \\
\hline $36-45$ th & 11 & 24,4 \\
\hline $46-55$ th & 3 & 6,7 \\
\hline $56-65$ th & 1 & 2,2 \\
\hline \multicolumn{3}{|l|}{ Pendidikan } \\
\hline SD & 5 & 11,1 \\
\hline SMP & 9 & 20 \\
\hline SMA & 31 & 68,9 \\
\hline \multicolumn{3}{|l|}{ Masa Kerja } \\
\hline$>2$ th & 33 & 73,3 \\
\hline$\leq 2 \mathrm{th}$ & 12 & 26,7 \\
\hline \multicolumn{3}{|l|}{ Jam Kerja } \\
\hline$>8$ jam/hari & 9 & 20,0 \\
\hline$\leq 8 \mathrm{jam} / \mathrm{hari}$ & 36 & 80,0 \\
\hline \multicolumn{3}{|l|}{ Kebiasaan Merokok } \\
\hline Merokok & 36 & 77,8 \\
\hline Tidak merokok & 9 & 22,2 \\
\hline \multicolumn{3}{|l|}{ Paparan (Pb) } \\
\hline Tidak normal $(>20 \mu \mathrm{g} / \mathrm{g})$ & 37 & 82,2 \\
\hline Normal $(\leq 20 \mu \mathrm{g} / \mathrm{g})$ & 8 & 17,8 \\
\hline
\end{tabular}

Tabel 2

Analisis Paparan Timbal (Pb) Berdasarkan Jam Kerja Pada Operator SPBU CV.Arba Di Kota Palu

\begin{tabular}{|c|c|c|c|c|c|c|c|}
\hline \multirow{3}{*}{ Jam Kerja } & \multicolumn{4}{|c|}{ Paparan $\mathbf{P b}$} & \multirow{3}{*}{ Total (N) } & \multirow{3}{*}{$\%$} & \multirow{3}{*}{ Value } \\
\hline & \multicolumn{2}{|c|}{ Tidak Normal } & \multicolumn{2}{|c|}{ Normal } & & & \\
\hline & $\mathbf{N}$ & $\%$ & $\mathbf{N}$ & $\%$ & & & \\
\hline $\begin{array}{l}\text { Tidak Normal } \\
\text { ( }>8 \text { jam/hari) }\end{array}$ & 4 & 44,4 & 5 & 55,6 & 9 & 100 & \\
\hline $\begin{array}{c}\text { Normal } \\
(\leq 8 \mathrm{jam} / \mathrm{hari})\end{array}$ & 33 & 91,7 & 3 & 8,3 & 36 & 100 & 0.004 \\
\hline Total (N) & 37 & 82,2 & 8 & 17,8 & 45 & 100 & \\
\hline
\end{tabular}


Tabel 3

Analisis Paparan Timbal (Pb) Berdasarkan Masa Kerja Pada Operator SPBU CV.Arba Di Kota Palu

\begin{tabular}{|c|c|c|c|c|c|c|c|}
\hline \multirow{3}{*}{ Masa Kerja } & \multicolumn{4}{|c|}{ Paparan $\mathbf{P b}$} & \multirow{3}{*}{ Total (N) } & \multirow{3}{*}{$\%$} & \multirow{3}{*}{ Value } \\
\hline & \multicolumn{2}{|c|}{ Tidak Normal } & \multicolumn{2}{|c|}{ Normal } & & & \\
\hline & $\mathbf{N}$ & $\%$ & $\mathbf{N}$ & $\%$ & & & \\
\hline Lama (>2th) & 32 & 97 & 1 & 3,0 & 33 & 100 & \\
\hline $\operatorname{Baru}(\leq 2 \mathrm{th})$ & 5 & 41,7 & 7 & 58,3 & 12 & 100 & 0.000 \\
\hline Total (N) & 37 & 82,2 & 8 & 17,8 & 45 & 100 & \\
\hline
\end{tabular}

Tabel 4

Analisis Paparan Timbal (Pb) Berdasarkan Kebiasaan Merokok Pada Operator SPBU CV.Arba Di Kota Palu

\begin{tabular}{ccccccccc}
\hline \multirow{2}{*}{$\begin{array}{c}\text { Kebiasaan } \\
\text { Merokok }\end{array}$} & \multicolumn{9}{c}{ Paparan Pb } & & \multirow{2}{*}{ Total (N) } & $\%$ & Value \\
\cline { 2 - 5 } & \multicolumn{1}{c}{ Tidak Normal } & Normal & & & & \\
\cline { 2 - 6 } Merokok & 34 & 94,4 & 2 & 5,6 & 36 & 100 & \\
Tidak Merokok & 3 & 33,3 & 6 & 66,7 & 9 & 100 & 0.001 \\
Total $(\mathrm{N})$ & 37 & 82,2 & 8 & 17,8 & 45 & 100 & \\
\hline
\end{tabular}

